\title{
Conversion of $\left[\mathrm{U}-{ }^{14} \mathrm{C}\right]$ Threonine into ${ }^{14} \mathrm{C}$-Labelled Amino Acids in the Brain of Thiamin-Deficient Rats
}

\author{
By M. K. GAITONDE \\ Medical Research Council Laboratories, Woodmansterne Road, Carshalton, Surrey SM5 4EF, U.K.
}

(Received 14 February 1975)

\begin{abstract}
In confirmation of the findings of Gaitonde et al. (1974), a decrease in the brain concentration of threonine and serine, and an increase in glycine, were observed in rats maintained on a thiamin-deficient diet. Similar changes were found in the blood, and the concentration of several other amino acids in the blood decreased significantly. There was a correlation between the concentrations of threonine, serine, aspartate and asparagine in the brain and blood. In experiments in which $\left[\mathrm{U}-{ }^{14} \mathrm{C}\right]$ threonine was injected into rats most of the radioactivity in the brain and blood of control rats was, as expected, in threonine in the acid-soluble metabolites. In contrast, a considerable proportion of radioactivity was also found in other amino acids, namely glutamate, glutamine, aspartate, $\gamma$-aminobutyrate and alanine, in the brain of thiamin-deficient rats. $\left[\mathrm{U}-{ }^{14} \mathrm{C}\right] \mathrm{Threonine}$ was also converted into ${ }^{14} \mathrm{C}$-labelled lactate and glucose, but the extent of this conversion was severalfold higher in thiamin-deficient than in control rats. This finding gave evidence of the stimulation in thiamin-deficient rats of the catabolism of $\left[\mathrm{U}-{ }^{14} \mathrm{C}\right]$ threonine to $\left[{ }^{14} \mathrm{C}\right]$ lactate by the aminoacetone pathway catalysed by threonine dehydrogenase, and into succinate via propionate by the $\alpha$-oxobutyrate pathway catalysed by threonine dehydratase (deaminase). The measurement of specific radioactivities of glutamate, aspartate and glutamine after injection of $\left[\mathrm{U}-{ }^{14} \mathrm{C}\right]$ threonine, and of lactate and glucose in the brain after injection of $\left[\mathrm{U}-{ }^{14} \mathrm{C}\right]$ threonine, indicated a stimulation of the activities of threonine dehydrogenase and threonine dehydratase (deaminase) in the brain of thiamin-deficient rats. The specific radioactivities of glutamate, aspartate and glutamine in the brain were consistent with an alteration in the metabolism of threonine, mainly in the 'large' compartment of the brain of thiamin-deficient rats. The measurement of relative specific radioactivity of proteins after injection of $\left[\mathrm{U}-{ }^{14} \mathrm{C}\right]$ threonine indicated a marked decrease in the synthesis of proteins, mainly in the liver of thiamin-deficient rats.
\end{abstract}

The maintenance of rats on a thiamin-deficient diet has been shown to result in a decrease in the concentration of glutamate, threonine and serine, and an increase of glycine, in the brain (Gaitonde et al., 1974). However, an acute deficiency of thiamin produced by injection of pyrithiamin, an antagonist of thiamin, to rats maintained on a thiamin-deficient diet showed more marked changes in the concentration of these and other amino acids of the brain, except that the concentration of threonine showed an increase instead of the expected decrease (Gaitonde et al., 1975). These variable changes in the concentration of threonine, an essential amino acid, in the brain suggested an alteration in the metabolic fate of threonine in thiamin deficiency in rats.

The present investigation was undertaken to follow the metabolic fate of $\left[\mathrm{U}-{ }^{14} \mathrm{C}\right]$ threonine in control and thiamin-deficient rats.

\section{Experimental}

\section{Animals}

Black hooded male rats of an inbred strain (white and grey) of the MRC Dunn Nutritional Laboratory,
Cambridge, U.K., were used. Littermates were separated into two groups; one group (the control group) was maintained on a thiamin-supplemented diet and the other group on a thiamin-deficient diet from day 24 after birth. The composition of the diet and other treatments were as described by Gaitonde et al. (1974).

The animals were used on day 46 after birth, i.e. after 22 days of maintenance on the special diet. The numbers of animals decapitated for measurement of metabolites in the brain and blood are given in appropriate Tables. The metabolism of threonine was studied by injecting four control and four thiamin-deficient rats subcutaneously with $0.5 \mathrm{ml}$ of a solution containing $5 \mu \mathrm{Ci}$ of carrier-free $\mathrm{L}-\left[\mathrm{U}-{ }^{14} \mathrm{C}\right]-$ threonine per $100 \mathrm{~g}$ body wt. Labelled threonine $(228 \mu \mathrm{Ci} / \mu \mathrm{mol})$ was purchased from The Radiochemical Centre, Amersham, Bucks., U.K. The animals were killed by decapitation at different times after injection. The brain was removed quickly, blotted on Whatman no. 50 paper and frozen in liquid $\mathrm{N}_{2}$ within $30-35 \mathrm{~s}$ after decapitation. Blood was collected from the severed neck into a $10 \mathrm{ml}$ beaker 
wetted with heparin. The tissue and blood were treated with ice-cold $5 \%(\mathrm{w} / \mathrm{v}) \mathrm{HClO}_{4}$ and the acid extract was neutralized with $\mathrm{KOH}$ as described (Gaitonde, 1974; Gaitonde et al., 1974). The total volume of the acid extract was calculated by assuming that $80 \%$ of the tissue weight or blood volume was water.

\section{Fractionation of metabolites}

Fractions containing(i) amino acids, (ii) free sugars, (iii) taurine, (iv) lactate, (v) sugar phosphates, nucleotide monophosphates, $N$-acetylaspartate and organic acids, and (vi) nucleotide triphosphates were obtained by ion-exchange chromatography of the neutralized $\mathrm{HClO}_{4}$ extract as described (Gaitonde et al., 1974, 1975).

\section{Tissue protein}

The tissue residue insoluble in $\mathrm{HClO}_{4}$ was treated a further six times with $5 \%(\mathrm{w} / \mathrm{v}) \mathrm{HClO}_{4}$. After each treatment the suspension was centrifuged for $20 \mathrm{~min}$ at $3000 \mathrm{rev} . / \mathrm{min}$ at between $4^{\circ}$ and $6^{\circ} \mathrm{C}$ and the supernatant solution was decanted and discarded. Lipids were extracted from the tissue residue sequentially by treatment with different organic solvents and the combined lipid extract was tested for radioactivity (Gaitonde \& Arnfred, 1971).

The final lipid-free residue contained RNA, DNA and protein; it was dried in air at room temperature $\left(20^{\circ} \mathrm{C}\right)$, weighed and designated tissue protein. A sample of the tissue protein was dissolved to give a concentration of $10 \mathrm{mg}$ dry wt./ml of $0.5 \mathrm{M}$ $\mathrm{NaOH}$ by treatment at $40^{\circ} \mathrm{C}$ for $24 \mathrm{~h}$. A portion $(1.0 \mathrm{ml})$ was acidified with $0.2 \mathrm{ml}$ of $98-100 \%(\mathrm{v} / \mathrm{v})$ formic acid and mixed with $10 \mathrm{ml}$ of a scintillation mixture of toluene and Triton X-100 for measurement of radioactivity (see Gaitonde, 1974). Another portion was diluted with $0.5 \mathrm{M}-\mathrm{NaOH}$ and analysed for protein content by the Technicon Autoanalyzer method (Gaitonde \& Arnfred, 1971). Proteins were hydrolysed by refluxing with $6 \mathrm{M}-\mathrm{HCl}$ for $24 \mathrm{~h}$.

\section{Analytical methods}

$\gamma$-Aminobutyrate was isolated with Amberlite CG $50\left(\mathrm{H}^{+}\right.$form) ion-exchange resin, glutamate, aspartate and GSSG with AG1 ion-exchange resin (acetate form; supplied by BioRad Laboratories, Richmond, Calif., U.S.A.), and other amino acids with Chromobeads type $A$ ion-exchange resin equilibrated with lithium citrate buffer, pH3.0. Since the concentrations of individual amino acids in the blood were not very different from each other, unlike those of glutamate, aspartate and glutamine in the brain, the amino acid fraction of the blood was chromatographed directly on a $130 \mathrm{~cm}$-long column of Chromobeads type $\mathrm{A}$ ion-exchange resin equilibrated with $0.275 \mathrm{M}$-lithium citrate, $\mathrm{pH} 2.7$. The amino acids were eluted with the same buffer, which gave a resolution of glutamine (up to $0.7 \mu \mathrm{mol}$ ) from

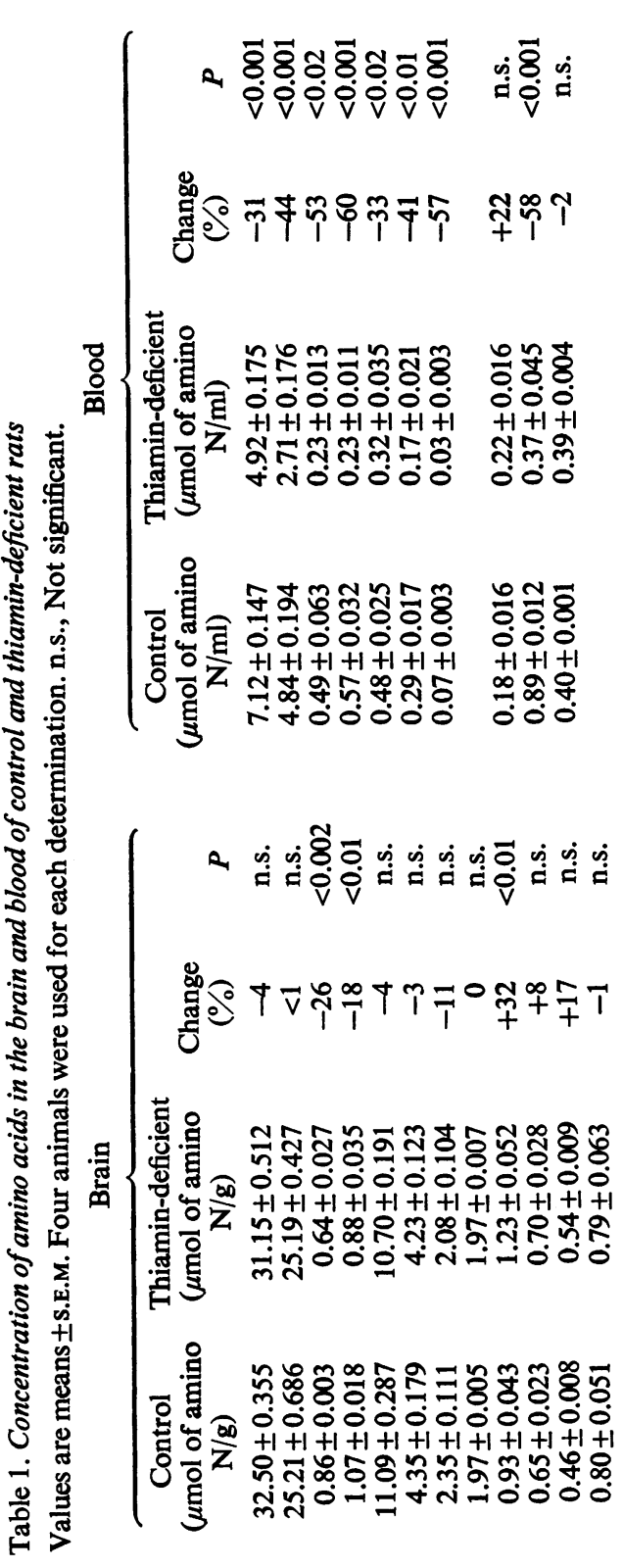

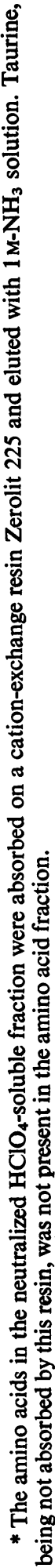


Table 2. Concentration of glucose, glucose 6-phosphate and lactate in brain and blood of control and thiamin-deficient rats

The brain was removed and frozen in liquid $\mathrm{N}_{2}$ within $30-35 \mathrm{~s}$ after decapitation of the animals. Values are means \pm S.E.M. with the number of determinations in parentheses. n.s., Not significant.

Brain

$\begin{array}{ccc}\begin{array}{c}\text { Control } \\ (\mu \mathrm{mol} / \mathrm{g})\end{array} & \begin{array}{c}\text { Thiamin- } \\ \text { deficient } \\ (\mu \mathrm{mol} / \mathrm{g})\end{array} & P \\ 0.36 \pm 0.01(20) & 0.52 \pm 0.02(23) & <0.001 \\ 0.07 \pm 0.003(19) & 0.07 \pm 0.004(24) & \text { n.s. } \\ 8.15 \pm 0.22(16) & 8.55 \pm 0.20(16) & \text { n.s. }\end{array}$

\begin{tabular}{|c|c|c|}
\hline \multicolumn{3}{|c|}{ Blood } \\
\hline $\begin{array}{c}\text { Control } \\
(\mu \mathrm{mol} / \mathrm{ml})\end{array}$ & $\begin{array}{l}\text { Thiamin- } \\
\text { deficient } \\
(\mu \mathrm{mol} / \mathrm{ml})\end{array}$ & $P$ \\
\hline $\begin{array}{l}6.42 \pm 0.27 \\
0.05 \pm 0.003 \\
1.84 \pm 0.23\end{array}$ & $\begin{array}{l}5.52 \pm 0.21 \\
0.05 \pm 0.002(7) \\
3.53 \pm 0.25\end{array}$ & $\begin{array}{l}<0.05 \\
\text { n.s. } \\
<0.001\end{array}$ \\
\hline
\end{tabular}

glutamate (up to $1.2 \mu \mathrm{mol}$ ) in the sample. Further details of methods for the quantitative determination of the concentrations and specific radioactivities of amino acids have been published (Gaitonde et al., 1974; Gaitonde, 1974).

The concentration and specific radioactivity of lactate (Gaitonde et al., 1974), glucose and glucose 6-phosphate (Gaitonde et al., 1975) were determined by enzymic methods.

\section{Results}

\section{Concentration of amino acids in brain and blood}

The total amino $\mathrm{N}$ content of the brain did not change in animals maintained on a thiamin-deficient diet (Table 1). However, as shown (Gaitonde et al., 1974), the concentrations of threonine and serine decreased whereas that of glycine increased significantly in the brain as a result of thiamin deficiency. In contrast, the total amino $\mathrm{N}$ content of the blood decreased significantly in thiamin-deficient rats, attributable largely to a decrease in threonine, serine, glutamate, glutamine, aspartate and alanine concentrations (Table 1). The blood glycine concentration showed some increase. A significant correlation between the concentrations of amino acids in brain and blood was found only for threonine $(r=0.841$, $n=12, P=0.001)$, serine $(r=0.853, n=12, P=$ $0.001)$, aspartate $(r=0.622, n=11, P=0.05)$ and asparagine $(r=0.573, n=12, P=0.05)$.

The individual amino acid concentrations in the brain of control rats used in the present investigation were lower than those reported by Gaitonde $e t$ al. (1974). In particular, threonine concentration in the brain of control rats used in the present work $(0.86 \mu \mathrm{mol} / \mathrm{g}$; Table 1$)$ was considerably lower than that reported $(1.09 \mu \mathrm{mol} / \mathrm{g})$ by Gaitonde et al. (1974). Also three out of 17 control brains (including the four used in the present work) gave threonine concentrations similar to those found in the brain of thiamin-deficient rats.

\section{Concentration of glucose, glucose 6-phosphate and lactate}

The blood lactate content of the thiamin-deficient rats was significantly higher and glucose content was correspondingly lower than in the control rats. As the animals were decapitated, glucose content $(0.36 \mu \mathrm{mol} / \mathrm{g}$; Table 2$)$ of the brain of control rats was considerably lower than that $(1.38 \mu \mathrm{mol} / \mathrm{g})$ reported by Veech \& Hawkins (1974), who obtained samples of brain from the animals by the freeze-blowing technique, which is claimed to give values of glycolytic intermediates very near to those in vivo. Despite the limitation of partial post-mortem glycolysis of glucose into lactate, a significant increase in brain glucose content was found in thiamin-deficient rats. This finding agrees with the results of experiments in which a deficiency of thiamin was produced by treatment of rats with pyrithiamin, an antagonist of thiamin (Holowach et al., 1968; Gaitonde et al., 1975).

A deficiency of thiamin, whether produced by feeding a thiamin-deficient diet alone as reported in the present work (Table 2) or by administering pyrithiamin as reported by Gaitonde et al. (1975), showed no changes in the concentration of glucose 6-phosphate in brain and blood.

Incorporation of ${ }^{14} \mathrm{C}$ in brain and blood constituents after injection of $\left[U-{ }^{14} \mathrm{C}\right]$ threonine

Information on the metabolic fate of injected [U- $\left.{ }^{14} \mathrm{C}\right]$ threonine was obtained by measurement of the radioactivity of fractions containing acid-soluble metabolites, lipids or proteins. Radioactivity was found in acid-soluble metabolites and proteins; the lipid fraction contained no measurable amount of radioactivity.

\section{Labelling of proteins}

Of the total ${ }^{14} \mathrm{C}$ content in blood, proteins accounted for $1 \%$ at $10 \mathrm{~min}$ and $30 \%$ at $30 \mathrm{~min}$ in the control rats; in contrast there was no detectable radioactivity at $10 \mathrm{~min}$ and $7 \%$ at $30 \mathrm{~min}$ in the thiamin-deficient rats (Table 3). Proteins in the brain, unlike those in blood, were labelled at $10 \mathrm{~min}$ after injection of $\left[\mathrm{U}_{-}{ }^{14} \mathrm{C}\right]$ threonine into thiamin-deficient as well as control rats. The percentage incorporation of ${ }^{14} \mathrm{C}$ into the brain proteins at $10 \mathrm{~min}$ was similar in both control and thiamin-deficient rats, but it was considerably less at $30 \mathrm{~min}$ in thiamin-deficient $(4 \%)$ than in the control $(13 \%)$ rats (Table 3 ). 


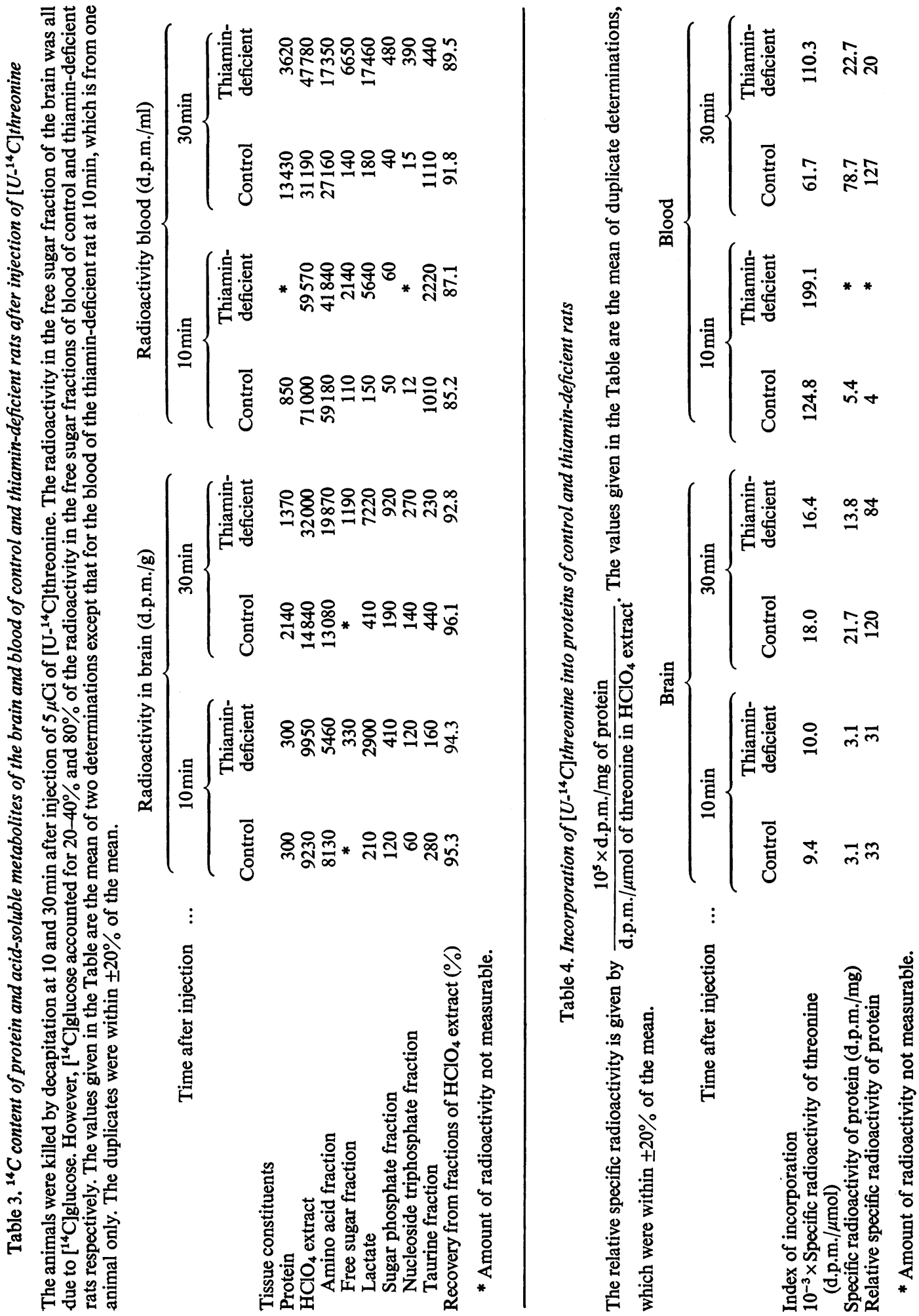


Ion-exchange chromatography of protein hydrolysates showed that the radioactivity in proteins from brain and blood was essentially due to incorporation of threonine, except that a small amount of radioactive glycine (4-6d.p.m./mg of protein) was also detectable in the blood proteins of the control rats $30 \mathrm{~min}$ after injection of $\left[\mathrm{U}-{ }^{14} \mathrm{C}\right]$ threonine. Other amino acids in proteins from the brain and blood contained a negligible amount of radioactivity (less than $25 \%$ of the background counting rate) in both the control and thiamin-deficient rats. These findings show that ${ }^{14} \mathrm{C}$-labelled glutamate, glutamine, aspartate and alanine found in the $\mathrm{HClO}_{4}$ extract of the brain of thiamin-deficient rats after injection of [U- $\left.{ }^{14} \mathrm{C}\right]$ threonine (see below) were not readily available for their incorporation into the proteins of brain.

The specific radioactivity of proteins, expressed as d.p.m./mg of protein of brain at $10 \mathrm{~min}$, was similar in both control and thiamin-deficient rats, but at $30 \mathrm{~min}$ the specific radioactivity of the protein of brain as well as blood was considerably less in thiamindeficient rats than in control rats (Table 4). The same conclusion may be drawn from measurement of relative specific radioactivity of proteins, an index of incorporation that corrects for differences in the specific radioactivity of precursor $\left[\mathrm{U}-{ }^{14} \mathrm{C}\right]$ threonine in the $\mathrm{HClO}_{4}$ extract (Table 4). Since liver is the main source of blood proteins, the observed marked decrease in the specific radioactivity and relative specific radioactivity of blood proteins indicates that the incorporation of $\left[\mathrm{U}-{ }^{14} \mathrm{C}\right]$ threonine into liver proteins decreased considerably in thiamin-deficient rats.

\section{Labelling of acid-soluble metabolites}

There was a decrease in ${ }^{14} \mathrm{C}$ in the acid-soluble metabolites of blood with time after injection of $\left[\mathrm{U}-{ }^{14} \mathrm{C}\right]$ threonine: in the control rats the value at
$30 \mathrm{~min}$ was approx. $44 \%$ of that at $10 \mathrm{~min}$, but it was approx. $80 \%$ in the thiamin-deficient rats (Table 3 ). Although the concentration of ${ }^{14} \mathrm{C}$ was considerably lower in the brain than in blood at 10 and $30 \mathrm{~min}$ after the injection of $\left[\mathrm{U}-{ }^{14} \mathrm{C}\right]$ threonine, the ${ }^{14} \mathrm{C}$ content of the brain increased during this period by approx. $60 \%$ in the control and $220 \%$ in the thiamin-deficient rats.

As expected, most of the radioactivity in the acidsoluble metabolites of both the brain and blood of control rats was in the amino acid fraction (Table 3). However, inspection of the distribution pattern of ${ }^{14} \mathrm{C}$ in several groups of metabolites revealed a distinct difference in two respects in the metabolic fate of $\left[\mathrm{U}-{ }^{14} \mathrm{C}\right]$ threonine between the control and thiamindeficient rats. (i) A significant proportion of the radioactivity in the acid-soluble extract was in lactate and free sugars of the blood and brain of thiamindeficient rats, and (ii) although small amounts of $\left[{ }^{14} \mathrm{C}\right]$ lactate and free sugars were found in the blood of control rats, only $\left[{ }^{14} \mathrm{C}\right]$ lactate was measurable in the brain of control rats.

A considerable proportion of ${ }^{14} \mathrm{C}$ was also found in the taurine fraction, which contains taurine, phosphoethanolamine and glycerophosphoethanolamine. The ${ }^{14} \mathrm{C}$-labelled compound in this fraction has not been identified. A small but measurable amount of radioactivity was also present in the sugar phosphate and nucleoside triphosphate fractions (Table 3).

${ }^{14} \mathrm{C}$ content of individual amino acids. Threonine accounted for $95-98 \%$ of the radioactivity of amino acids in the brain and blood of control rats after the injection of $\left[\mathrm{U}-{ }^{14} \mathrm{C}\right]$ threonine. Of the several amino acids examined only glutamate $(0.5-1.0 \%)$ in brain, and glycine $(0.05-0.5 \%)$ and serine $(0.3-0.4 \%)$ in blood, were found labelled at 10 and $30 \mathrm{~min}$. In view of the isotopic resolution of ${ }^{12} \mathrm{C}$-labelled and ${ }^{14} \mathrm{C}$ -

Table 5. Incorporation of ${ }^{14} \mathrm{C}$ into amino acids of brain and blood of thiamin-deficient rats after injection of $\left[U-{ }^{14} C\right]$ threonine

The radioactivity in the amino acid fraction of control rat brain and blood was essentially in threonine (see the text). The values given are means of duplicate determinations which were within $\pm 5 \%$ of the mean.

${ }^{14} \mathrm{C}$ in the amino acid fraction $(\%)$

\begin{tabular}{|c|c|c|c|c|c|}
\hline & & & & & \\
\hline & & & & & \\
\hline & Time after injection $\ldots$ & $10 \mathrm{~min}$ & $30 \mathrm{~min}$ & $10 \mathrm{~min}$ & $30 \mathrm{~min}$ \\
\hline Threonine & & 82.3 & 46.1 & 95.9 & 81.1 \\
\hline Serine & & 0.6 & 0.1 & 0.4 & 0.4 \\
\hline Glutamate & & 10.0 & 25.1 & * & * \\
\hline Glutamine & & 3.1 & 10.9 & * & * \\
\hline Aspartate & & 3.0 & 8.2 & * & * \\
\hline$\gamma$-Aminobutyrate & & 1.3 & 3.2 & & \\
\hline Alanine & & 0.6 & 0.9 & * & * \\
\hline Glycine & & * & * & 0.3 & 0.2 \\
\hline GSSG & & 0.8 & 1.3 & & \\
\hline
\end{tabular}

* Amount of radioactivity not measurable. 
labelled amino acids on ion-exchange resin columns (Gaitonde \& Nixey, 1972), the presence of a small amount of radioactivity in serine is probably due to overlapping traces of $\left[{ }^{14} \mathrm{C}\right]$ threonine.

In contrast, a considerable proportion of radioactivity in amino acids of the brain after injection of [U- $\left.{ }^{14} \mathrm{C}\right]$ threonine into thiamin-deficient rats was found also in other amino acids, namely glutamate, glutamine, aspartate, $\gamma$-aminobutyrate, alanine and the tripeptide glutathione (Table 5).

The recovery of ${ }^{14} \mathrm{C}$ after ion-exchange chromatography of the amino acid fraction was between 96 and $102 \%$ for both brain and blood, except that the amino acid fraction of blood obtained at $30 \mathrm{~min}$ after injection to thiamin-deficient rats only, gave a recovery of $82 \%$ of the radioactivity.

\section{Discussion}

Whereas essentially all the radioactivity in the acidsoluble fraction of the brain was in threonine in the control rats, a considerable proportion of the radioactivity in this fraction of the brain of thiamindeficient rats was also in lactate, glucose and amino acids, particularly those closely associated with the tricarboxylic acid cycle. Clearly $\left[\mathrm{U}-{ }^{14} \mathrm{C}\right]$ threonine injected into thiamin-deficient rats was catabolized, and this raises the question of the pathways of its catabolism and the site of catabolism, i.e. whether the injected $\left[\mathrm{U}-{ }^{14} \mathrm{C}\right]$ threonine was catabolized in the brain or whether the ${ }^{14} \mathrm{C}$-labelled catabolic products of $\left[\mathrm{U}-{ }^{14} \mathrm{C}\right]$ threonine were transported to the brain from other organs by the bloodstream.

\section{Labelled metabolites in blood}

The incorporation of ${ }^{14} \mathrm{C}$ into blood glucose and lactate after injection of [U-14 $\mathrm{C}]$ threonine was greatly enhanced by thiamin deficiency. The $\left[{ }^{14} \mathrm{C}\right]$ glucose must originate in the liver and kidney by gluconeogenesis from the $\left[\mathrm{U}-{ }^{14} \mathrm{C}\right]$ threonine, most probably via the $\alpha$-oxobutyrate pathway of threonine catabolism. For the enzymes governing the three catabolic pathways of threonine (see Scheme 1) the highest activities reported have been with the liver dehydratase and methylmalonyl-CoA mutase, enzymes of the $\alpha$ oxobutyrate pathway (Greenberg, 1961; Goldstein et al., 1962). It is also noteworthy that the amount of $\left[{ }^{14} \mathrm{C}\right]$ glucose was $5-15$-fold that of $\left[{ }^{14} \mathrm{C}\right]$ lactate, and that aspartate, glutamate, glutamine and alanine were labelled in the blood at 10 and $30 \mathrm{~min}$ after subcutaneous injection of $\left[2-{ }^{14} \mathrm{C}\right]$ propionate (an intermediate on the $\alpha$-oxobutyrate pathway) in control rats (M. K. Gaitonde, unpublished work). However, the ${ }^{14} \mathrm{C}$ content of blood lactate after injection of [U- $\left.{ }^{14} \mathrm{C}\right]$ threonine was similar to that of glucose in control rats and 2-3-fold that of glucose in thiamin-deficient rats (Table 3); the specific radioactivity of lactate was 3-8-fold that of glucose

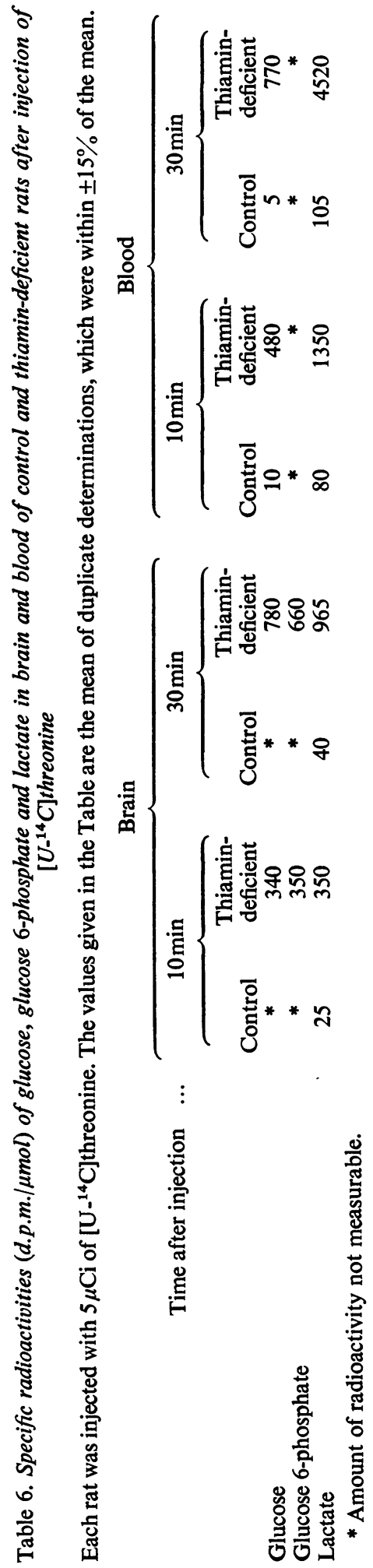


Table 7. Specific radioactivities of amino acids in the brain of thiamin-deficient rats after injection of $\left[U-{ }^{14} C\right]$ threonine

Only glutamate contained a measurable amount of radioactivity (specific radioactivity 5 at $10 \mathrm{~min}$ and 11 at $30 \mathrm{~min}$ ) in the brain of control rats. The duplicate determinations at $10 \mathrm{~min}$ were within $\pm 10 \%$ of the mean value given.

Sp. radioactivity (d.p.m./ $\mu \mathrm{mol})$

\begin{tabular}{lcccc} 
& Time after injection & $\ldots$ & \multicolumn{2}{c}{$30 \mathrm{~min}$} \\
Glutamate & & & $\overbrace{\text { Expt. (i) }}^{\text {Expt. (ii) }}$ \\
Glutamine & 70 & 680 & 320 \\
Aspartate & 50 & 600 & 280 \\
y-Aminobutyrate & 140 & 950 & 470 \\
Alanine & 50 & 490 & 200 \\
& 60 & 270 & 180
\end{tabular}

in blood and similar in brain (Table 6). Moreover, since aspartate, alanine, glutamate and glutamine were not labelled in measurable amounts in the blood of thiamin-deficient rats (Table 5 ), $\left[{ }^{14} \mathrm{C}\right]$ lactate formed via pyruvate by decarboxylation of oxaloacetate derived by the $\alpha$-oxobutyrate pathway in these animals must be considered negligible. It is concluded that the greater proportion of $\left[{ }^{14} \mathrm{C}\right]$ lactate was derived from $\left[\mathrm{U}-{ }^{14} \mathrm{C}\right]$ threonine by the aminoacetone pathway, as originally proposed for the catabolism of threonine (and utilization of glycine) in bacterial cells and animal tissues (Elliott, 1959; Green \& Elliott, 1964). Taking account of all observations it would appear that both threonine dehydratase and threonine dehydrogenase activities are stimulated in thiamin deficiency.

The main source of $\left[{ }^{14} \mathrm{C}\right]$ lactate and $\left[{ }^{14} \mathrm{C}\right]$ glycine in blood must be liver and kidney, where $\left[\mathrm{U}-{ }^{14} \mathrm{C}\right]-$ threonine may be converted into amino $\left[{ }^{14} \mathrm{C}\right]$ acetone by threonine dehydrogenase (Green \& Elliott, 1964), or by aminoacetone synthetase (Urata \& Granick, 1963) after the conversion of $\left[\mathrm{U}_{-}{ }^{14} \mathrm{C}\right]$ threonine into $\left[{ }^{14} \mathrm{Clglycine}\right.$ by threonine aldolase (Braunshtein \& Vilenkina, 1949; Lin \& Greenberg, 1954; Karasek \& Greenberg, 1957; Malkin \& Greenberg, 1964; Riario-Sforza et al., 1969). Aminoacetone is a normal constituent of urine and its excretion in urine is increased on administration of threonine to rats (Marver et al., 1966). Direct conversion of $\left[\mathrm{U}-{ }^{14} \mathrm{C}\right]$ threonine into amino $\left[{ }^{14} \mathrm{C}\right]$ acetone in blood is ruled out in view of the absence of threonine dehydrogenase from rat blood (Green \& Elliott, 1964). Although reported present in duck erythrocytes (Meltzer \& Sprinson, 1952) and chicken erythrocytes (Gibson et al., 1958), threonine aldolase and aminoacetone synthetase also are probably not present in rat blood and this would exclude the possibility of synthesis of amino $\left[{ }^{14} \mathrm{C}\right]-$ acetone in blood from $\left[\mathrm{U}-{ }^{14} \mathrm{C}\right]$ threonine. Further oxidation of amino $\left[{ }^{14} \mathrm{C}\right]$ acetone to $\left[{ }^{14} \mathrm{C}\right]$ lactate must have occurred in rat liver and kidney in view of the presence in these tissues of amine oxidase (Urata \&
Granick, 1963), aminoacetone-2-oxoglutarate aminotransferase (Urata \& Granick, 1963), methylglyoxalase(Dakin \& Dudley, 1913; Ariyama, 1928; Dickens, 1933; Jowett \& Quastel, 1934; Platt \& Schroeder, 1934; Hopkins \& Morgan, 1948) and D-lactatecytochrome $c$ reductase (Tubbs \& Greville, 1961). $\mathrm{L}-\left[{ }^{14} \mathrm{C}\right]$ Lactate, finally formed from $\left[{ }^{14} \mathrm{C}\right]$ pyruvate in these tissues by L-lactate dehydrogenase, would be transported into the blood. Alternatively, a part of the amino $\left[{ }^{14} \mathrm{C}\right]$ acetone formed in the tissues was transported to the blood, where it was converted into $\left[{ }^{14} \mathrm{C}\right]-$ lactate via $\left[{ }^{14} \mathrm{C}\right]$ methylglyoxal by the catalytic action of amine oxidase (Elliott, 1960; Buffoni \& Blaschko, 1963) and methylglyoxalase (Dakin \& Dudley, 1913; Ariyama, 1928; Jowett \& Quastel, 1933). Brain may also be considered a source of blood-borne $\left[{ }^{14} \mathrm{C}\right]-$ lactate (see below).

The aldolase activity, with the formation of glycine, accounts for $20-33 \%$ of threonine catabolized in normal animals (Meltzer \& Sprinson, 1952). In the present investigation the evidence for the activity of this enzyme was obtained in all control rats and only in some thiamin-deficient rats. The absence of $\left[{ }^{14} \mathrm{C}\right]$ glycine from the brain agrees with the reported absence of threonine aldolase from rat brain (Braunshtein \& Vilenkina, 1949) and indicates that brain cannot be a source of $\left[{ }^{14} \mathrm{C}\right] g l y c i n e$ in the blood.

\section{Labelled metabolites in brain}

The conversion of threonine into $\alpha$-oxobutyrate was demonstrated in rat brain preparations (Salvatore et al., 1966) and $\alpha$-oxobutyrate was oxidatively decarboxylated to propionate by pigeon brain preparations (Long, 1943). Further oxidation of propionate to succinate was catalysed by mitochondrial enzymes in mammalian brain (Beck et al., 1957). In view of the absence of any measurable amount of radioactivity in aspartate in the brain of control rats at 10 and $30 \mathrm{~min}$ after injection of $\left[\mathrm{U}-{ }^{14} \mathrm{C}\right]$ threonine, catabolism of threonine by the $\alpha$-oxobutyrate path-

Vol. 150 
way in the brain of control rats must be considered negligible. If this pathway was operating in the brain, aspartate would be the first amino acid to be labelled from $\left[\mathrm{U}-{ }^{14} \mathrm{C}\right]$ threonine in the brain and its specific radioactivity would be expected to be higher than that of glutamate and glutamine. This was indeed the case in the brain of thiamin-deficient rats (Table 7). The higher labelling of aspartate in the brain could not have been due to the entry of ${ }^{14} \mathrm{C}$-labelled propionate (and presumably ${ }^{14} \mathrm{C}$-labelled $\alpha$-oxobutyrate) formed by catabolism of $\left[\mathrm{U}-{ }^{14} \mathrm{C}\right]$ threonine in liver, because intraperitoneally administered $\left[{ }^{14} \mathrm{C}\right]$ propionate has been reported to give the specific radioactivity of aspartate considerably less than that of glutamate (approx. 61-73\%; O'Neal et al., 1966). Also the ${ }^{14} \mathrm{C}$ content of aspartate was approx. $35 \%$ of that of glutamate at $30 \mathrm{~min}$ after injection of $\left[\mathrm{U}-{ }^{14} \mathrm{C}\right]$ threonine (Table 5); if the labelling of aspartate was exclusively by metabolism of blood-borne $\left[{ }^{14} \mathrm{C}\right]$ glucose in the brain the ${ }^{14} \mathrm{C}$ content of aspartate would be expected to be approx. $20 \%$ (Gaitonde et al., 1974). It is therefore concluded that, unlike in the control rats, a part of the injected [U- $\left.{ }^{14} \mathrm{C}\right]$ threonine is catabolized by the $\alpha$-oxobutyrate pathway to aspartate in the brain of thiamin-deficient rats. In the light of the present evidence in favour of increased threonine dehydratase activity in the brain of thiamin-deficient rats, it is suggested that the reported variable concentrations of threonine dehydratase in liver (Nishimura \& Greenberg, 1961; Doonan et al., 1974) may be related to thiamin concentrations in animal liver.

Since radioactive glucose was not present in measurable amounts in the brain of control rats after injection of $\left[\mathrm{U}-{ }^{14} \mathrm{C}\right]$ threonine, it could not have been the source of labelled lactate in their brain. The evidence for the entry of blood-borne $\left[{ }^{14} \mathrm{C}\right]$ lactate into the brain was obtained by O'Neal \& Koeppe (1966) for adult rats and Cremer \& Heath (1974) for 17-dayold suckling rats. A calculation based on the data of Cremer \& Heath (1974) for the amount and specific radioactivity of lactate in brain after injection of $\left[{ }^{14} \mathrm{C}\right]$ lactate shows that $\left[{ }^{14} \mathrm{C}\right]$ lactate content (d.p.m./g) in the brain of 17-day-old suckling rats was approx. $30 \%$ of that in the blood (d.p.m./ml). It may be assumed that this value is likely to be considerably less in the older rats, e.g. in the 46-day-old rats used in the present investigation, owing to the operation of the blood-brain barrier. The ${ }^{14} \mathrm{C}$ content of brain lactate found in the present work after injection of [U- ${ }^{14} \mathrm{C}$ ] threonine was approx. $189 \pm 32 \%$ (s.E.M.) of that in the blood of control rats and therefore indicates that it cannot be due to trapped blood in the brain and that not all $\left[{ }^{14} \mathrm{C}\right]$ lactate found in the brain could have been due to the entry of blood-borne $\left[{ }^{14} \mathrm{C}\right]$ lactate. Therefore it is suggested that $\left[{ }^{14} \mathrm{C}\right]$ lactate in the brain of control rats was derived partly by direct entry in vivo of blood-borne $\left[{ }^{14} \mathrm{C}\right]$ lactate and partly by catabolism of $\left[\mathrm{U}-{ }^{14} \mathrm{C}\right]$ threonine in the brain by the aminoacetone pathway. Moreover, in thiamindeficient rats, a part of brain $\left[{ }^{14} \mathrm{C}\right]$ lactate must also be due to glycolysis, in vivo and post mortem, of bloodborne $\left[{ }^{14} \mathrm{C}\right] g l u c o s e$ in the brain.

The conclusion that a part of the $\left[\mathrm{U}-{ }^{14} \mathrm{C}\right]$ threonine in the brain was converted into lactate by the aminoacetone pathway agrees with the reported presence in the brain of threonine dehydrogenase, a mitochondrial enzyme (Green \& Elliott, 1964), amine oxidase, also a mitochondrial enzyme (Urata \& Granick, 1963) and methylglyoxalase (Dakin \& Dudley, 1913; Jowett \& Quastel, 1934; Ariyama, 1928), although evidence is lacking for the occurrence of D-lactatecytochrome $c$ reductase.

\section{Site of catabolism of $\left[U-{ }^{14} C\right]$ threonine in the brain}

The results of previous investigations on the labelling of glutamate, glutamine, aspartate and $\gamma$-aminobutyrate after injection of different ${ }^{14} \mathrm{C}$-labelled precursors have given evidence for the concept of a 'small' and a 'large' glutamate compartment in the brain. The labelling of amino acids is presumed to occur in the 'small' compartment if the observed specific radioactivity of glutamine is greater than that of glutamate, and in the 'large' compartment if otherwise. [For references on this subject see reviews by Balázs et al. (1973), Berl (1973), Cremer (1973) and Van den Berg (1973).]

In the present investigation the specific radioactivity of aspartate was higher than that of glutamate after injection of $\left[\mathrm{U}-{ }^{14} \mathrm{C}\right]$ threonine. This finding is similar to that to be expected after injection of $\left[{ }^{14} \mathrm{C}\right]$ succinate (Möhler et al., 1974). However, the fact that the specific radioactivity of glutamine was not greater than that of glutamate in the present investigation (Table 7), unlike that in experiments after injection of ${ }^{14} \mathrm{C}$-labelled succinate (Möhler et al., 1974), propionate (O’Neal et al., 1966) or leucine (Patel \& Balázs, 1970), suggests that the labelling of amino acids from $\left[\mathrm{U}-{ }^{14} \mathrm{C}\right]$ threonine must have occurred mainly in the 'large' compartment, as in experiments after injection of ${ }^{14} \mathrm{C}$-labelled glucose (Cremer, 1964; Gaitonde et al., 1965) and lactate (O'Neal \& Koeppe, 1966). Provided that the 'large' compartment is part of the neuronal elements (Balázs et al., 1973), it is suggested that the metabolism of threonine, an essential amino acid, in the neuronal compartment is altered in thiamin deficiency in the rat so that some threonine is catabolized for the synthesis of aspartate, glutamate, glutamine and $\gamma$-aminobutyrate by the aminoacetone and $\alpha$-oxobutyrate pathways as shown in Scheme 1 . In view of the multiplicity of the precursors such as ${ }^{14} \mathrm{C}$-labelled lactate, succinate and glucose formed by the catabolism of [ $\left.\mathrm{U}-{ }^{14} \mathrm{C}\right]$ threonine, the results of the present investigation do not provide estimates of the relative contributions of labelling of amino acids by these precursors. 


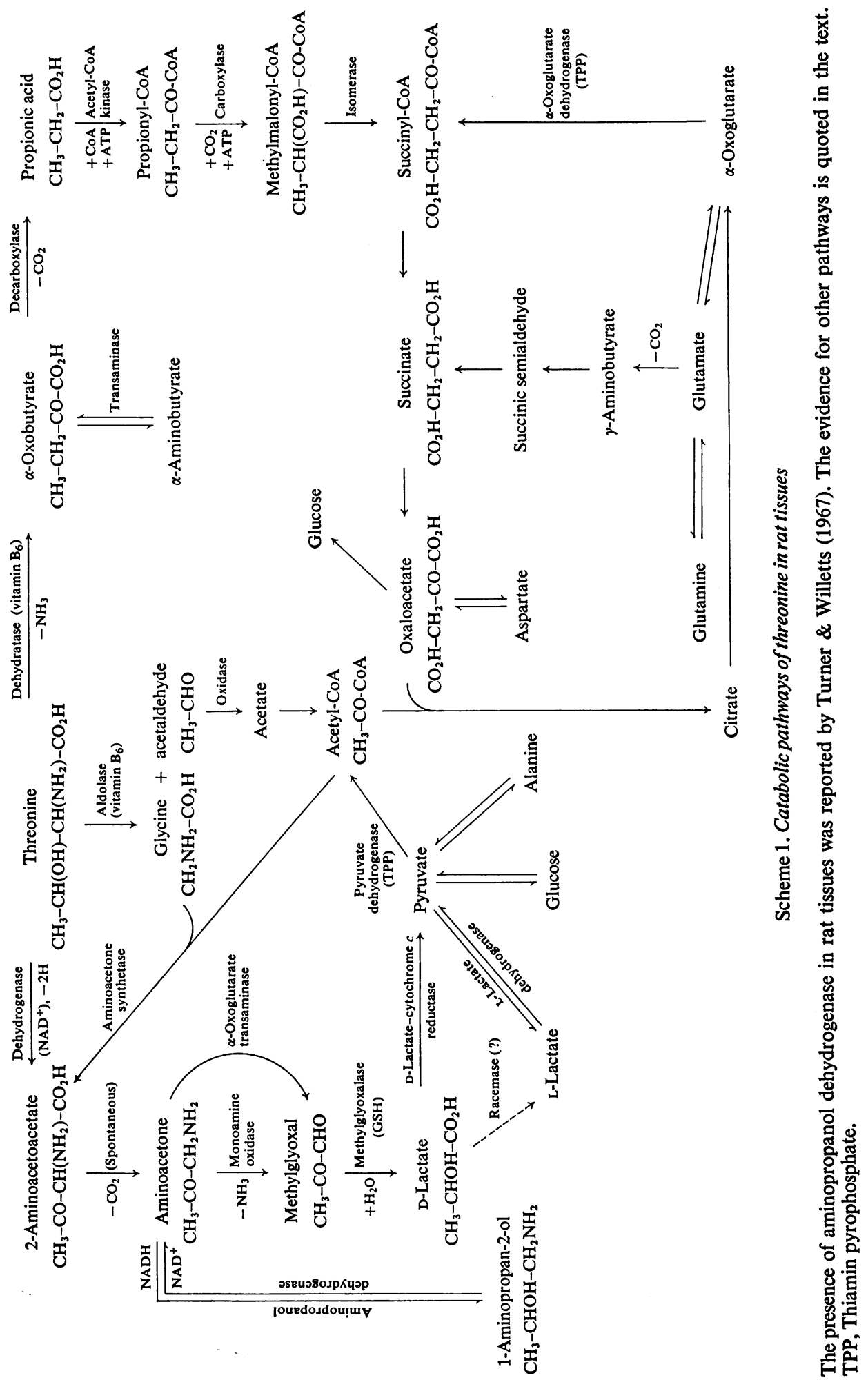

Vol. 150 
Stimulation of enzymes and amino acid concentrations in the brain

The relevance of a deficiency of thiamin to the apparent stimulation of threonine dehydrogenase and threonine dehydratase is not obvious from the catabolic pathways of threonine shown in Scheme 1 . Threonine dehydratase of rat liver is shown to be inducible under a variety of conditions, such as starvation (Pitot et al., 1958), administration of threonine or proteins (Sayre et al., 1956; Goldstein et al., 1962; Pitot \& Peraino, 1964; Yamashita et al., 1968), glucocorticoids (Peraino et al., 1966; Peraino, 1967; $\mathrm{Ku}$ et al., 1969) and experimentally induced diabetes (Ishikawa et al., 1965). It therefore appears likely that partial starvation in the thiamin-deficient rats was responsible for the apparent enhanced activity of threonine dehydratase and perhaps that of threonine dehydrogenase in the rat. If so, the results of the present investigation suggest that the activities of these two enzymes are induced in the brain, as well as in other organs, by dietary factors such as those imposed by a deficiency of thiamin in the diet. Since the conversion of $\left[\mathrm{U}-{ }^{14} \mathrm{C}\right]$ glucose into brain amino acids was decreased in thiamin-deficient rats (Gaitonde et al., 1974), the stimulation of threonine dehydratase and threonine dehydrogenase in the brain of thiamindeficient rats would enable the brain to utilize threonine, an essential amino acid, as an alternative source of precursor for the synthesis of aspartate, glutamate, glutamine and $\gamma$-aminobutyrate.

I am indebted to Dr. I: M. Sharman of the MRC Dunn Nutritional Laboratory for providing thiamin-deficient rats. I also thank Miss Julie Thompson and Mrs. Catherine Potter for excellent technical assistance.

\section{References}

Ariyama, N. (1928) J. Biol. Chem. 77, 359-395

Balázs, R., Patel, A. J. \& Richter, D. (1973) in Metabolic Compartmentation in the Brain (Balázs, R. \& Cremer, J. E., eds.), pp. 167-184, The Macmillan Press, London

Beck, W. S., Flavin, M. \& Ochoa, S. (1957) J. Biol. Chem. 229, 997-1010

Berl, S. (1973) in Metabolic Compartmentation in the Brain (Balázs, R. \& Cremer, J. E., eds.), pp. 3-17, The Macmillan Press, London

Braunshtein, A. E. \& Vilenkina, G. Y. (1949) Doklady Akad. Nauk SSSR 66 243-246; Chem. Abstr. 43, $7986 \mathrm{f}$

Buffoni, F. \& Blaschko, H. (1963) Experientia 19, 421

Cremer, J. E. (1964) J. Neurochem. 11, 165-185

Cremer, J. E. (1973) in Metabolic Compartmentation in the Brain (Balázs, R. \& Cremer, J. E., eds.), pp. 81-93, The Macmillan Press, London

Cremer, J. E. \& Heath, D. F. (1974) Biochem. J. 142, 527543

Dakin, H. D. \& Dudley, H. W. (1913) J. Biol. Chem. 15, 463-474

Dickens, F. (1933) Nature (London) 131, 130-131
Doonan, S., Koerner, D. H., Schmutzler, W. \& Vernon, C. A. (1974) Biochem. J. 144, 533-541

Elliott, W. H. (1959) Nature (London) 183, 1051-1052

Elliott, W. H. (1960) Nature (London) 185, 467-468

Gaitonde, M. K. (1974) in Research Methods in Neurochemistry (Marks, N. \& Rodnight, R., eds.), vol. 2, pp. 321-359, Plenum Press, New York

Gaitonde, M. K. \& Arnfred, T. (1971) J. Neurochem. 18, 1971-1987

Gaitonde, M. K. \& Nixey, R. W. K. (1972) Anal. Biochem. 50, 416-429

Gaitonde, M. K., Dahl, D. R. \& Elliott, K. A. C. (1965) Biochem. J. 94, 345-352

Gaitonde, M. K., Nixey, R. W. K. \& Sharman, I. M. (1974) J. Neurochem. 22, 53-61

Gaitonde, M. K., Fayein, N. A. \& Johnson, A. L. (1975) J. Neurochem. 24, 1215-1223

Gibson, K. D., Laver, W. G. \& Neuberger, A. (1958) Biochem. J. 70, 71-81

Goldstein, L., Knox, W. E. \& Behrman, E. J. (1962) J. Biol. Chem. 237, 2855-2860

Green, M. L. \& Elliott, W. H. (1964) Biochem. J. 92, 537549

Greenberg, D. M. (1961) in Metabolic Pathways (Greenberg, D. M. ed.), vol. 2, pp. 69-172, Academic Press, New York

Holowach, J., Kauffman, F., Ikossi, M. G., Thomas, C. \& McDougal, D. B., Jr. (1968) J. Neurochem. 15, 621-631

Hopkins, F. G. \& Morgan, E. J. (1948) Biochem. J. 42, 2327

Ishikawa, E., Ninagawa, T. \& Suda, M. (1965) J. Biochem. (Tokyo) 57, 506-513

Jowett, M. \& Quastel, J. H. (1933) Biochem. J. 27, 486-498

Jowett, M. \& Quastel, J. H. (1934) Biochem. J. 28, 162-172

Karasek, M. A. \& Greenberg, D. M. (1957) J. Biol. Chem. 227, 191-205

Ku, Y., Rogers, Q. R. \& Harper, A. E. (1969) Proc. Soc. Exp. Biol. Med. 130, 556-563

Lin, S. C. \& Greenberg, D. M. (1954) J. Gen. Physiol. 38, 181-196

Long, C. (1943) Biochem. J. 37, 215-225

Malkin, L. I. \& Greenberg, D. M. (1964) Biochim. Biophys. Acta 85, 117-131

Marver, H. S., Tschudy, D. P., Perloth, M. G., Collins, A. \& Hunter, G., Jr. (1966) Anal. Biochem. 14, 53-60

Meltzer, H. L. \& Sprinson, D. B. (1952) J. Biol. Chem. 197, 461-474

Möhler, H., Patel, A. J. \& Balázs, R. (1974) J. Neurochem. 22, 1281-1289

Nishimura, J. S. \& Greenberg, D. M. (1961) J. Biol. Chem. 236, 2684-2691

O’Neal, R. M. \& Koeppe, R. E. (1966) J. Neurochem. 13, 835-847

O’Neal, R. M., Koeppe, R. E. \& Williams, E. I. (1966) Biochem. J. 101, 591-597

Patel, A. J. \& Balázs, R. (1970) J. Neurochem. 17, 955-971

Peraino, C. (1967) J. Biol. Chem. 242, 3860-3867

Peraino, C., Lamar, C. \& Pitot, H. C. (1966) J. Biol. Chem. 241, 2944-2948

Pitot, H. C. \& Peraino, C. (1964) J. Biol. Chem. 239, 17831788

Pitot, H. C., Dent, J. H. \& Feary, T. (1958) Fed. Proc. Fed. Am. Soc. Exp. Biol. 17, 290 
Platt, M. E. \& Schroeder, E. F. (1934) J. Biol. Chem. 106, 179-190

Riario-Sforza, G., Pagani, R. \& Marinello, E. (1969) Eur. J. Biochem. 8, 88-92

Salvatore, F., Zappia, V. \& Cortese, R. (1966) Enzymologia 31, 113-127

Sayre, F. W., Jensen, D. \& Greenberg, D. M. (1956) J. Biol. Chem. 219, 111-117

Tubbs, P. K. \& Greville, G. D. (1961) Biochem. J. 81, 104 114
Turner, J. M. \& Willetts, A. J. (1967) Biochem. J. 102, 511519

Urata, G. \& Granick, S. (1963) J. Biol. Chem. 238, 811-820

Van den Berg, C. J. (1973) in Metabolic Compartmentation in the Brain (Balázs, R. \& Cremer, J. E., eds.), pp. 137166, The Macmillan Press, London

Veech, R. L. \& Hawkins, R. A. (1974) in Research Methods in Neurochemistry (Marks, N. \& Rodnight, R., eds.), vol. 2, pp. 171-182, Plenum Press, New York

Yamashita, M., Eto, T., Fujimaki, M. \& Sakurai, Y.(1968) Agr. Biol. Chem. 32, 374-378 